\title{
Наталія ДЯЧУК,
}

orcid.org/0000-0002-5000-1816

аспірант кафедри англійської філології та методики навчання англійської мови Тернопільського начіонального педагогічного університету імені Володимира Гнатюка

(Тернопіль, Україна) shpenyk@gmail.com

\section{ОСОБЛИВОСТІ ФОРМУВАННЯ АНГЛОМОВНОЇ АУДИТИВНОЇ КОМПЕТЕНТНОСТІ СТАРШОКЛАСНИКІВ НА ОСНОВІ ВИКОРИСТАННЯ ПОДКАСТІВ}

\begin{abstract}
У статті подано визначення поняття аудіювання та розглянуто основні особливості формування іншомовних аудитивних навичок та умінь учнів на заняттях з іноземної мови у школі. Проаналізовано роль психофізіологічних механізмів пам'яті, уваги, мовленнєвого слуху та антиципації у формуванні аудитивної компетентності старшокласників. Визначено взаємозв'язок між правильною організачією прочесу аудіювання, механізмом антиципації та досягненням успіху в процесі сприйняття та розуміння тексту. Розглянуто типи антиципації та фактори, щзо впливають на їх формування. Описано основні фактори, щчо впливають на сприйняття та розуміння учнями аудіотексту. Проаналізовано особливості старшого шкільного віку та їх вплив на навчання учнів i формування пізнавального інтересу. Подано аналіз основних видів труднощів формування іншомовної аудитивної компетентності учнів та підкреслено важливість правильної організації діяльності учнів на заняттях для формування позитивного ставлення учнів до іноземної мови, створення сприятливої атмосфери на занятті та формування стійкого інтересу в учнів до вивчення мови. Наголочено на взаємозв'язку між формуванням різних видів іншомовних умінь у процесі вивчення англійської мови та окреслено роль автентичних матеріалів у формуванні англомовної аудитивної компетентності учнів стариих класів та їхніх комунікативних умінь. Охарактеризовано поняття подкасту та подано класифікацію основних видів подкастів. Визначено етапи роботи учнів з подкастами та перелічено види завдань, які сприятимуть досягненню успіху учнями на кожному з иих етапів. Розглянуто джерела подкастингу, способи використання подкастів на заняттях з англійської мови, їх иүінність як джерела автентичного мовлення, інформації соиіокультурного та краӥнознавчого характеру, проаналізовано вплив подкастів на формування аудитивних навичок і вмінь учнів та формування мотивачії до вивчення іноземної мови загалом.
\end{abstract}

Ключові слова: аудитивна компетентність, подкаст, аудіоподкаст, учні старших класів, труднощі аудіювання, антищипація.

\author{
Nataliia DIACHUK, \\ orcid.org/0000-0002-5000-1816 \\ Postgraduate Student at the Department of English Philology and Methods of Teaching English \\ Ternopil Volodymyr Hnatiuk National Pedagogical University \\ (Ternopil, Ukraine) shpenyk@gmail.com
}

\section{THE DEVELOPMENT HIGH SCHOOLS STUDENTS' ENGLISH LISTENING SKILLS ON THE BASIS OF PODCASTS}

The article defines the concept of listening and considers the main features of the development of students' foreign language listening skills during foreign language classes at school. The role of psychophysiological mechanisms of memory, attention, speech perception and anticipation in the development of students' listening skills in high school is analyzed. The relationship between the proper organization of the listening process, the mechanism of anticipation and successful perception and understanding of the text is determined. Types of anticipation and factors influencing their formation are considered. The main factors influencing students'perception and understanding of oral texts are described. Peculiarities of senior school age and their influence on students'learning and the development of their cognitive interest are analyzed. The analysis of the main types of difficulties in the development of students' foreign language listening skills is provided and the importance of the proper organization of students' work in class in developing their positive attitude to foreign language learning is emphasized. The article pays attention to the importance of creating a favorable atmosphere in class and its connection with making students interested in learning. Emphasis is placed on the relationship between the developments of different types of foreign language skills in the process of learning English. The article outlines the role of authentic materials in the formation of high school students' English listening skills and their foreign communication skills. The concept of podcasts is described and the classification of the main types of podcasts is given. The stages of students 'work with podcasts are identified and the types of tasks that will contribute to students'success of at 
each of these stages are listed. The sources of podcasting, ways to use podcasts in English classes, their value as sources of authentic speech and socio-cultural information is analyzed, as well as the impact of podcasts on the development of students' listening skills and motivation to learn a foreign language in general.

Key words: listening competence, podcast, audio podcast, high school students, listening difficulties, anticipation.

Постановка проблеми. Володіння іноземними мовами є важливою умовою сьогодення. Знання іноземних мов дає можливість не лише обмінюватися досвідом із представниками інших культур, але й дізнаватися важливу інформацію про наукові чи технологічні досягнення та відкриття, здійснені представниками інших країн. Знання іноземної мови дає змогу учням покращувати власний рівень цієї ж мови у процесі спілкування 3 однолітками 3 інших країн. У подальшому це дає можливість вибрати професію за сферою їхніх інтересів та досягти успіху у ній. За таких умов вивчення іноземних мов у школі, особливо в старших класах, коли випускники готуються до майбутньої професії, набуває особливого значення.

Метою вивчення англійської мови, як і будьяких інших іноземних мов, $є$ формування комунікативної компетентності як основи для вільного спілкування мовою. Комунікативна компетентність охоплює аудитивні уміння, навички та вміння говоріння, читання та письма. Часто процес формування аудитивної компетентності недооцінюється, у результаті чого мало уваги приділяється прослуховуванню аудіоматеріалу чи перегляду відеороликів англійською мовою, або учням пропонуються для прослуховування неавтентичні тексти, що не дає змоги належним чином сформувати комунікативні вміння учнів. У результаті цього ними значно легше сприймається інформація, яка була прочитана, ніж текст, сприйнятий на слух. Такі прогалини у знаннях та уміннях учнів можуть призвести до непорозумінь у процесі реального спілкування і завадять ним стати повноцінними учасниками процесу спілкування.

Аналіз досліджень. Питання формування іншомовної аудитивної компетентності неодноразово було об'єктом досліджень сучасних учених, таких як С. Гапонова, Н. Слухіна, М. Заболотна, М. Кабанова, О. Петращук, Н. Скляренко, O. Тарнопольський, С. Ніколаєва. Зокрема, I. Зимня, Г. Костюк та О. Леонтьєв розглядають психолінгвістичні передумови формування іншомовних аудитивних умінь; Н. Агєєва досліджує стратегії формування аудитивної компетентності; О. Тарнопольський визначає фактори, що сприяють формуванню іншомовних аудитивних умінь; С. Ніколаєва та О. Петращук розглядають питання тестового контролю для перевірки рівня сформованості аудитивних умінь учнів.

Актуальність питання формування англомовної аудитивної компетентності на основі подкастів зумовлена зростанням вимог до іншомовної підготовки учнів шкіл і недостатньою зорієнтованістю вітчизняних шкіл на ці постійно зростаючі вимоги.

Мета статті - розглянути основні механізми процесу аудіювання та на основі психофізіологічних особливостей учнів старшого класу обгрунтувати доцільність використання подкастів для формування їх англомовної аудитивної компетентності.

Виклад основного матеріалу. Для того щоби визначити ефективні шляхи формування аудитивних навичок та умінь учнів, необхідно з'ясувати визначення поняття «аудіювання» та його основні характеристики. Аудіювання - це рецептивний вид мовленнєвої діяльності, за допомогою якого здійснюється сприйняття інформації на слух та їі розуміння (Тарнопольський, 2006: 124). Аудіювання $\epsilon$ активним процесом, що грунтується на природніх здібностях людини. У процесі індивідуального розвитку та за допомогою систематичного вправляння у сприйнятті інформації на слух аудитивні вміння постійно вдосконалюються. Це дає змогу сприймати інформацію, зберігати її у пам'яті, вибирати важливі дані, упускаючи несуттєві, аналізувати почуте та давати йому оцінку 3 огляду на власні переконання чи інтереси, а також згідно 3 поставленими завданнями (Бігич, 2012: 21).

Процес аудіювання $є$ комплексною мовленнєвою діяльністю, яка грунтується на психофізіологічних механізмах сприйняття та антиципації (Ніколаєва та ін., 2002: 119). Розуміння тексту на слух розпочинається 3 процесу його сприйняття, коли слухач сприймає інформацію, закодовану у вигляді звуків та їх комбінацій. При цьому його завдання полягає у правильному розшифруванні почутої інформації. Задля цього потік звуків поділяється слухачем на окремі сегменти для того, щоб виділити фонеми, слова та фразові й понадфразові єдності. При цьому в довготривалій пам’яті слухач підбирає відповідне значення слова, тип граматичної конструкції, зіставляє інтонацію, визначаючи мету висловлювання для правильної інтерпретації. Таким чином, процеси сприйняття, впізнавання та 
Аячук Н. Осоьливості формування ангмомовної аудитивної компетентності...

розуміння є основою процесу аудіювання. Успішність формування англомовної аудитивної компетентності залежить від особливостей слухової пам'яті реципієнта, тобто від обсягу інформації, яка може утримуватися ним в оперативній пам'яті. Сприйняття інформації на слух $є$ неможливим без механізму внутрішнього промовляння, за допомогою якого почуті звукові образи перетворюються на артикуляційні. Не менш важливими психофізіологічними механізмами аудіювання $є$ мовленнєвий слух, за допомогою якого слухач розпізнає фонеми та інтонацію, з якою повідомляється інформація, або ймовірнісне прогнозування (Бігич, 2012: 20; Бредихина, 2018: 15).

Говорячи про особливості старшого шкільного віку, який співпадає із закінченням підліткового періоду та початком періоду юнацтва, зазначаємо, що у цей період відбувається завершення формування механізмів вибіркового сприйняття та довільної уваги (Скрипченко, 2007: 202). Це дає змогу значно розширити можливості навчання старшокласників, розвитку їхньої розумової діяльності, а також формування комунікативної компетентності та аудитивних навичок як іiі компоненту. Старшокласники готові до більших розумових навантажень та виконання складніших завдань, що сприятиме швидшому та більш ефективному формуванню навичок англомовного аудіювання. Водночас завдання, які пропонуються учням, повинні відповідати їхньому рівню знань та умінь, оскільки надто складні завдання не дадуть змогу сформувати мотивацію до вивчення англійської мови та сформують помилкове враження непосильності завдань, які ставить перед ними вчитель.

Успішність формування англомовних аудитивних навичок старшокласників залежить від сформованості в них мовленнєвого слуху. Розрізняють інтонаційний та фонематичний мовленнєвий слух (Бігич, 2012: 20). Завдяки ним слухач здатен впізнавати в потоці мовлення звуки та зіставляти їх 3 уже знайомими йому образами, сприймати інтонацію словосполучення чи речення та зіставляти iii $з$ відомими інтонаційними моделями та їхнім смисловим навантаженням. Достатній рівень сформованості в учнів мовленнєвого слуху дає змогу розрізняти у процесі сприйняття окремі смислові одиниці та їхні характерні особливості, що дає можливість правильно зрозуміти інформацію, закодовану мовцем, і належним чином реагувати на повідомлення, підтримуючи процес іншомовної комунікації.

Правильна організація процесу аудіювання під час занять дасть змогу активувати процес анти- ципації. Належна установка на слухання (шляхом повідомлення учням теми аудіотексту чи пояснення їм мети прослуховування) дасть можливість налаштувати органи артикуляції на процес сприйняття (Бредихина, 2018: 15), що дасть змогу слухачам відгадати продовження речення чи словосполучення на основі почутих слів чи початкових фрагментів лексичних одиниць.

Учені розрізняють лінгвістичну та смислову антиципацію. Перша формується на основі навички з'єднання лексичних одиниць у словосполучення. Знаючи те, які слова поєднуються між собою і яким чином, учні здатні спрогнозувати інформацію, яка буде подана далі. Уміння смислової антиципації формуються на основі особистого мовного досвіду слухача, його знань та навичок спілкування. Наявність достатньої кількості знань про оточуючий світ та достатня компетентність у тій чи іншій сфері допомагають збагатити лексичний запас учнів, що дасть змогу більш точно та правильно спрогнозувати інформацію під час прослуховування (Бредихина, 2018: 16).

Для старшого шкільного віку є характерною спрямованість у майбутнє, що важливо враховувати під час підбору навчального матеріалу, зокрема аудіотекстів для прослуховування на заняттях з англійської мови. У цей період значно підвищується інтерес до навчання, що має професійну спрямованість (Скрипченко, 2007: 210-212). Учні цікавляться різноманітними джерелами інформації, що слід врахувати під час організації занять і підборі завдань. У старшокласників посилюється потреба у самостійному здобутті знань, у результаті чого за ретельного підбору завдань, які відповідатимуть інтересам учнів, можна досягнути ефективних результатів у процесі формування аудитивної компетентності. Пропонуючи учням цікаві автентичні аудіо- та відеоматеріали, викладач зможе спонукати їх до самостійного вдосконалення власних аудитивних умінь і навичок іншомовної комунікації загалом.

Не менш важливою психофізіологічною особливістю старшого шкільного віку є вдосконалення пам'яті (Скрипченко, 2007: 212). Окрім збільшення об'єму пам'яті, спостерігається зміна способів запам'ятовування інформації. Окрім мимовільного запам'ятовування, яке $\epsilon$ характерним для молодших учнів, старшокласники значною мірою покладаються на довільне запам'ятовування. Це означає, що на цьому етапі вивчення іноземної мови їм можна пропонувати складніші тексти для прослуховування, що можуть містити інформацію абстрактного характеру (наприклад, аудіоматеріали про відносини 
між людьми, тексти економічної тематики чи тексти, що містять цінні поради стосовно вибору майбутньої професії та досягнення успіху в ній). Оскільки старшокласники здатні не лише механічно запам'ятовувати почутий матеріал, але й широко використовувати різноманітні техніки запам'ятовування задля збільшення продуктивності власної пам'яті (Скрипченко, 2007: 212), процес формування англомовної аудитивної компетентності можна поєднувати з удосконаленням лексичної чи граматичної компетентності, тренуючи використання лексичних одиниць чи граматичних структур, почутих в аудіотексті у процесі усної чи письмової комунікації.

Для учнів старших класів характерним $є$ вміння переключати довільну увагу і залишатися довгий час зосередженими на матеріалі, особливо якщо він входить до сфери їхніх інтересів. Цікаві автентичні матеріали на зразок подкастів, фрагментів теле- чи радіопередач дадуть змогу привернути увагу учнів і тривалий час утримувати іiі на необхідному об'єкті. Це допоможе створити ситуацію успіху на заняттях чи під час виконання завдань для самостійного опрацювання вдома, що сприятиме ефективному формуванню англомовної аудитивної компетентності.

Злагоджена взаємодія механізмів сприйняття, уваги та пам'яті сприяє осмисленню та розумінню матеріалу, який сприймається на слух. Механізм осмислення функціонує як результат аналітико-синтетичної діяльності мозку (Бредихина, 2018: 16), що дає змогу слухачеві відібрати важливу інформацію, не звертати уваги на деталі, які не $є$ важливими для розуміння сутності повідомлення чи для виконання поставленого перед ним завдання на аудіювання. Таким чином, у пам'яті звільняється місце для подальшої інформації, яка буде важливою для осмислення матеріалу.

Успішність процесу аудіювання залежить не лише від психофізіологічних особливостей дітей старшого шкільного віку, але й від мовних особливостей аудіотексту, наявності фонетичних, лексичних чи граматичних труднощів, а також від умов сприйняття повідомлення (Хмизова, 2019: 169). Безпосереднє спілкування, в процесі якого слухач бачить мовця, його міміку та жести, є легшим, оскільки вищезгадані екстралінгвістичні фактори полегшують процес розуміння, тоді як сприйняття та розуміння аудіозапису є складнішими. Крім того, діалогічне мовлення є складнішим для розуміння, оскільки, окрім звичного сприйняття інформації на слух, учні повинні також ідентифікувати мовців і пам'ятати інформацію, яка повідомлялася кожним із них, що вимагає додаткових аналітико-синтетичних дій (Бігич, 2012: 23; Хмизова, 2019: 169; Ніколаєва, 2002: 126-128).

Фонетичні труднощі аудіювання виникають за умов недостатньо розвиненого фонематичного слуху та відсутності належного рівня сформованості навичок вимови. Складними для сприйняття учнями є явища редукції, асиміляції, розпізнавання інтонаційних моделей. Велике значення мають також темп мовлення та його емоційність. Емоційне мовлення є простішим для сприйняття, ніж логічна інтонація, оскільки воно є схожим в усіх мовах, зокрема в англійській та українській (Корунець, 2004: 99-101; Бігич, 2012: 22).

Лексичні труднощі передусім зумовлюються наявністю незнайомих для учнів лексичних одиниць в аудіоповідомленні, оскільки вони є своєрідним психологічним бар'єром для розуміння повідомлення. Часто, зосереджуючи надмірну увагу на таких лексичних одиницях, учень не звертає увагу на важливу інформацію, яка $є$ необхідною для правильного розуміння тексту. Оскільки тексти для старшокласників є складними та часто містять фразові дієслова, лексичні одиниці, вжиті в переносному значенні, чи фразеологічні звороти, це також становить додаткові труднощі для розуміння (Ніколаєва, 2002: 125). Для правильного розуміння такого лексичного матеріалу необхідно пам'ятати контекст, у якому він знаходиться в тексті. Труднощі також становлять багатозначні слова та наявність синонімів у тексті, а також лексичні одиниці, котрі $є$ схожими за вимовою до рідної мови, проте мають інше лексичне значення. Виконання дотекстових вправ та обговорення 3 учнями нових чи складних для розуміння лексичних одиниць на етапі підготовки до прослуховування тексту сприятимуть усуненню можливих лексичних труднощів аудіювання.

Граматичні труднощі пов'язані зі сприйняттям та розумінням складних чи нових для учнів синтаксичних конструкцій (Ніколаєва, 2002: 125). Це особливо актуально для учнів старших класів, коли аудіотексти, які пропонуються для прослуховування, є складними за будовою, містять значну кількість складносурядних та складнопідрядних речень, а також конструкцій, які відсутні в рідній мові. Сприйняття складних граматичних структур відбувається шляхом розчленування їх на окремі елементи, встановлення логічних зв'язків між ними, що матиме результатом правильне їх розуміння та розуміння смислу аудіотексту загалом. Достатня кількість виправлень у використанні складних чи нових для старшокласників конструкцій до прослуховування тексту, в якому вони траплятимуться, дасть змогу уникнути труднощів 
Аячук Н. Осоьливості формування ангмомовної аудитивної компетентності...

розуміння їх під час сприйняття на слух. Таким чином, можна зробити висновок про взаємозв'язок різних видів мовленнєвої діяльності та усіх компонентів іншомовної комунікативної компетентності й необхідність їх комплексного формування.

Процес формування англомовних аудитивних умінь старшокласників вимагає правильної організації навчального процесу та ретельного відбору навчального матеріалу. Підвищення інтересу до школи та навчання у старших класах дає можливість сформувати стійкий інтерес до вивчення англійської мови, що дасть змогу досягнути успіху у формуванні аудитивних умінь учнів. Використання автентичних матеріалів дає можливість урізноманітнити процес формування слухових навичок та умінь, підвищити мотивацію та покращити результати у навчанні. Вони не лише слугують зразками мовлення, але й характеризуються емоційністю змісту та виступають додатковим джерелом інформації про особливості культури країни, мову якої учні вивчають. Таким чином, процес формування англомовної аудитивної компетентності $є$ тісно пов'язаним та сприяє збагаченню соціокультурних та країнознавчих знань старшокласників, що $є$ важливим для успішного здійснення процесу іншомовної комунікації. Аудіокниги, подкасти та фільми є автентичним та цікавим джерелом інформації для старшокласників.

Розвиток інформаційних та інтернет-технологій дає змогу використовувати на заняттях 3 англійської мови велике різноманіття навчальних матеріалів, серед яких провідне місце посідають подкасти. Подкастинг $є$ відносно новим форматом поширення контенту мережею Інтернет, проте він часто використовується як в Україні, так і за кордоном. Подкаст - це аудіоблог чи передача, що поширюється мережею Інтернет із певною періодичністю (Кардашова, 2015: 178). Такі аудіоблоги чи передачі мають на меті формування умінь аудіювання та присвячені певній тематиці. Велике різноманіття подкастів дає змогу вчителеві вибирати ті, які відповідають мовним навичкам учнів і тематиці заняття. Більш того, подкасти є цікавою та зручною альтернативою радіо чи традиційним аудіотекстам, які використовуються на заняттях 3 англійської мови. Їх можна завантажити на телефон, ноутбук чи планшет і прослухати у зручний час (зокрема, безпосередньо на занятті чи вдома у процесі виконання домашнього завдання або задля поглиблення знань учнів і покращення їхніх аудитивних умінь).

Перевагою подкастів $є$ не лише наявність різноманітної тематики та рівнів складності, але й те, що значна їх кількість має транскрипти, що робить зручним їх використання на заняттях та дає змогу після прослуховування здійснювати аналіз граматичних конструкцій чи лексичних одиниць, вжитих в аудіотексті. Завдяки цьому одночасно 3 удосконаленням аудитивних умінь учнів учитель може закріплювати 3 ними пройдений граматичний чи лексичний матеріал. Водночас використання подкастів дає змогу формувати інформаційну компетентність, створює умови для міжкультурної взаємодії та дає можливість здійснювати індивідуальний підхід до викладання англійської мови (Давиденко, Пономаренко, 2018: 43), що є особливо важливим для учнів старших класів, для яких характерними $€$ підвищення пізнавального інтересу та потреба в набутті нових знань.

Учені класифікують подкасти на такі три основні типи, як відеоподкасти, аудіоподкасти та скрінкасти (Тихонова, 2011: 130-131). Скрінкасти часто використовуються у сфері комп'ютерних технологій, наприклад, для пояснення особливостей користування певними програмами. Під час створення скрінкастів відбувається запис діяльності користувача на екрані комп'ютера, що супроводжується аудіокоментарями, які використовуються для роз'яснення (Глушок, 2017: 101). Такі подкасти не лише будуть цікавими, оскільки містять лексику, пов'язану 3 популярними комп'ютерними технологіями, якими цікавиться молодь, але й виконуватимуть навчальну та інформативну функції, оскільки, окрім знання лексики, старшокласники зможуть набути нових знань щодо користування корисними програмами, що може стати в нагоді в їхній майбутній професійній діяльності.

За особливістю створення подкасти поділяють на подкасти, створені вчителями для їхніх учнів; автентичні подкасти (створені носіями мови); учнівські або студентські подкасти (Глушок, 2017: 101). Таке різноманіття джерел подкастингу свідчить про широкий діапазон їхнього використання. Вони можуть слугувати джерелом і зразком автентичного мовлення, засобом перевірки знань учнів та сприяти формуванню творчого підходу до вивчення англійської мови. Після прослуховування подкасту на певну тематику учням можна пропонувати створити власні подкасти, що сприятиме закріпленню вивченого матеріалу, вдосконаленню фонетичних навичок та сформує в учнів навички групової роботи (такі творчі завдання можуть виконуватися як кожним учнем індивідуально, так і в невеликих групах). Створюючи такі подкасти, учні можуть розміщувати їх у мережі 
Інтернет, завдяки чому вони матимуть можливість отримати широку аудиторію слухачів, а це сприятиме підвищенню мотивації до вивчення англійської мови та відповідальному підходу до виконання домашніх завдань.

Робота 3 подкастами передбачає такі ж етапи, як і під час опрацювання аудіотекстів, а саме підготовчий етап, безпосереднє прослуховування подкасту та етап перевірки розуміння прослуханого тексту. Підготовчий етап передбачає ознайомлення учнів із завданням та опрацювання складного для них лексичного й граматичного матеріалу, котрий зустрічатиметься в тексті. Учням пропонується дати відповіді на запитання, спрогнозувати інформацію, яку вони почують в аудіотексті. Під час підготовчого етапу вчитель повідомляє учнів, скільки разів вони прослуховуватимуть текст та які завдання вони виконуватимуть після цього.

Етап безпосереднього прослуховування передбачає сприйняття та розуміння учнями аудіотексту. Під час нього учні можуть проаналізувати почуту інформацію та перевірити власні здогадки. Перевірка розуміння учнями прослуханого $є$ завершальним етапом роботи 3 подкастом. Учням пропонуються завдання, котрі вимагають заповнення пропусків у реченнях, відповіді на запитання, відбору правильної відповіді чи визначення правдивості або неправдивості тверджень. Етап після прослуховування дає змогу вчителеві запропонувати учням завдання творчого характеру, зокрема вони можуть записати власний подкаст на ту ж тему чи записати подкаст, що буде продовженням прослуханого на уроці. Такі завдання сприятимуть ефективному формуванню навичок англомовного аудіювання старшокласників та дадуть змогу сформувати стійку мотивацію до вивчення мови, оскільки учні зможуть бачити практичне застосування власних знань і вмінь.

Висновки. Підсумовуючи зазначене вище, можемо стверджувати, що використання сучасних інформаційних технологій дає змогу урізноманітнити заняття 3 англійської мови та створити творче середовище для вивчення мови. Подкасти $\epsilon$ джерелом цікавої інформації для учнів, сприяють формуванню аудитивної компетентності та $\epsilon$ зразком автентичного мовлення. Використання таких завдань на заняттях відповідає пізнавальним потребам старшокласників, дає змогу задіяти емоційну пам'ять, що сприяє досягненню кращих результатів у формуванні навичок аудіювання старшокласників та формуванню англомовної комунікативної компетентності загалом.

\section{СПИСОК ВИКОРИСТАНИХ ДЖЕРЕЛ}

1. Бігич О. Методика формування іншомовної компетентності в аудіюванні. Іноземні мови. 2012. № 2. С. 19-30.

2. Бредихина И. Методика преподавания иностранных языков: Обучение основным видам речевой деятельности : учебное пособие. Екатеринбург : изд-во Уральского университета, 2018. 104 с.

3. Скрипченко О. та ін. Вікова та педагогічна психологія : навчальний посібник. 2-ге вид. Київ : Каравела, 2007. $400 \mathrm{c}$.

4. Глушок Л. Використання подкастів і блогів у процесі формування професійної компетентності майбутніх вчителів англійської мови. Наукові записки Національного університету «Острозька академія». 2017. С. $100-103$.

5. Давиденко О., Пономаренко О. Подкастинг як засіб формування компетентності в англомовному аудіюванні студентів молодших курсів. Science Rise: Pedagogical Education. 2018. № 5. С. 43-46.

6. Кардашова Н. Англомовний подкаст як засіб формування компетентності в аудіюванні студентів мовних спеціальностей. Вісник КНЛУ. Серія: Педагогіка та психологія. 2015. № 24. С. 176-185.

7. Корунець І. Порівняльна типологія англійської та української мов : навчальний посібник. Вінниця : Нова книга, 2004. 464 c.

8. Ніколаєва С. та ін. Методика викладання іноземних мов у середніх навчальних закладах : підручник. 2-ге вид. Київ : Ленвіт, 2002. 328 с.

9. Тарнопольський О. Методика навчання іншомовної мовленнєвої діяльності у вищому мовному закладі освіти : навчальний посібник. Київ : ІНКОС, 2006. 248 с.

10. Тихонова Е. Использование современных электронных устройств как средство повышения эффективности интеграции интернет-технологий в лингвообразовательное пространство. Современные модели в преподавании иностранных языков и культур в контексте менеджмента качества образования : сборник материалов V Всероссийской (с международным участием) научно-методической конференции. Москва : РГСУ, 2011. С. 127-140.

11. Хмизова О. Формування навичок аудіювання у студентів-медиків. Теорія $і$ методика професійної освіти. 2019. № 14. T. 1. C. 167-170.

\section{REFERENCES}

1. Bihych O. Metodyka formuvannia inshomovnoi kompetentnosti v audiiuvanni. Inozemni movy. [Methods of developing foreign language listening skills]. 2012. № 2. S. 19-30 [in Ukrainian].

2. Bredykhyna Y. Metodika prepodavaniya inostrannyih yazyikov: Obuchenie osnovnyim vidam rechevoy deyatelnosti: ucheb. posobye [Methods of teaching foreign languages]. Ekaterynburh : Yzd-vo Uralskoho un-ta, 2018. 104 s [in Russian]. 
3. Vikova ta pedahohichna psykholohiia : navch. posib. [Age-group and pedagogical psychology] / O. Skrypchenko ta in. 2-e vyd. Kyiv : Karavela, 2007. $400 \mathrm{~s}$ [in Ukrainian].

4. Hlushok L. Vykorystannia podkastiv i blohiv u protsesi formuvannia profesiinoi kompetentnosti maibutnikh vchyteliv anhliiskoi movy. [The use of podcasts and blogs in the process of forming the professional competence of future English teachers]. Naukovi zapysky Natsionalnoho universytetu "Ostrozka akademiia". 2017. S. 100-103 [in Ukrainian].

5. Davydenko O., Ponomarenko O. Podkastynh yak zasib formuvannia kompetentnosti v anhlomovnomu audiiuvanni studentiv molodshykh kursiv [Podcasting as a means of forming competence in English listening to junior students]. Journal “ScienceRise: Pedagogical Education. 2018. № 5. S. $43-46$ [in Ukrainian].

6. Kardashova N. Anhlomovnyi podkast yak zasib formuvannia kompetentnosti $\mathrm{v}$ audiiuvanni studentiv movnykh spetsialnostei [English-language podcast as a means of forming competence in listening to students of language specialties]. Visnyk KNLU. Seriia Pedahohika ta psykholohiia. 2015. № 24. S. 176-185 [in Ukrainian].

7. Korunets I. Porivnialna typolohiia anhliiskoi ta ukrainskoi mov : navch. Posibnyk [The comparative typology of the English and Ukrainian languages]. Vinnytsia : Nova knyha, 2004. $464 \mathrm{~s}$ [in Ukrainian].

8. Metodyka vykladannia inozemnykh mov u serednikh navchalnykh zakladakh : pidruchnyk [Methods of teaching foreign languages in secondary schools] / S. Yu. Nikolaieva ta in. 2-e vyd. Kyiv : Lenvit, 2002. $328 \mathrm{~s}$ [in Ukrainian].

9. Tarnopolskyi O. Metodyka navchannia inshomovnoi movlennievoi diialnosti u vyshchomu movnomu zakladi osvity: navchalnyi posibnyk [Methods of teaching foreign language speaking skills in a higher language educational institution]. Kyiv : INKOS, 2006. $248 \mathrm{~s}$ [in Ukrainian].

10. Tihonova E. Ispolzovanie sovremennyih elektronnyih ustroystv kak sredstvo povyisheniya effektivnosti integratsii Internet-tehnologiy $\mathrm{v}$ lingvoobrazovatelnoe prostranstvo. [The use of modern electronic devices as a means of increasing the efficiency of the integration of Internet technologies into teaching languages]. Sovremennyie modeli v prepodavanii inostrannyih yazyikov i kultur v kontekste menedzhmenta kachestva obrazovaniya : sb. materialov V Vseros. (s mezhdunar. uchastiem) nauch.-metod. konf. Moskva : RGSU, 2011. S. 127-140 [in Russian].

11. Khmyzova O. Formuvannia navychok audiiuvannia u studentiv-medykiv [Developing medical students' listening skills]. Teoriia i metodyka profesiinoi osvity. 2019. № 14. T. 1. S. 167-170 [in Ukrainian]. 